\title{
IMPLEMENTASI STRATEGI PEMBELAJARAN MENULIS BERBASIS MULTIPLE INTELLIGENCES
}

\author{
Suniyah \\ Muhammad Rohmadi \\ Edy Tri Sulistiyo \\ Universitas Sebelas Maret \\ Jl. Ir. Sutami No.36 A, Pucangsawit, Jebres, Kota Surakarta, Jawa Tengah \\ Email: nie.yach@gmail.com
}

\begin{abstract}
The study aims to describe the implementation of learning strategies based on multiple intelligences at SD Islamic International School PSM Magetan. This research is a qualitative descriptive study in the form of a case study. The data in this study are places and events, informants, and documents. The sampling technique used was purposive sampling and snowball sampling. First results show that the learning planning process based on multiple intelligences at the Islamic International School Elementary School PSM Magetan runs well in the form of implementing Multiple Intelligence Research (MIR) preparation of AP, IP, SOW, LP, and authentic assessment instruments. Second results show that the teacher integrates various methods with the types of multiple intelligences of students in writing learning, with authentic assessment. Constraints faced by teachers and schools in the implementation of writing learning strategies based on multiple intelligences can be addressed properly.
\end{abstract}

Keywords: multiple intelligences, learning strategies, writing skills

\begin{abstract}
Abstrak: Penelitian bertujuan mendeskripsikan implementasi strategi pembelajaran menulis berbasis multiple intelligences di SD Islamic International School PSM Magetan. Penelitian ini merupakan penelitian deskriptif kualitatif dalam bentuk studi kasus. Data dalam penelitian ini adalah tempat dan peristiwa, informan, dan dokumen. Teknik cuplikan yang digunakan purposive sampling dan snowball sampling. Hasil: (1) proses perencanaan pembelajaran menulis berbasis multiple intelligences di SD Islamic International School PSM Magetan berjalan dengan baik berupa pelaksanaan MultipleIintelligences Research (MIR) penyusunan dokumen AP, IP, SOW, LP, dan instrumen penilaian autentik. (2) guru mengintegrasikan berbagai berbagai metode dengan jenis-jenis kecerdasan majemuk siswa di dalam pembelajaran menulis, dengan penilaian autentik. Kendala yang dihadapi guru dan sekolah dalam implementasi strategi pembelajaran menulis berbasis multiple intelligences dapat diatasi dengan baik.
\end{abstract}

Kata kunci: multiple intelligences, strategi pembelajaran, keterampilan menulis

Sebagai institusi resmi dalam bidang pendidikan, sekolah memiliki peran yang sangat krusial dalam pembentukan dan pengembangan potensi peserta didik. Melalui sistem pendidikan yang diterapkan di sekolah, pengembangan potensi dan pembentukan perilaku individu diharapkan mampu mencapai perkembangan yang optimal.Namun demikian, pada pelaksanaannya berbagai hambatan dan prob- lematika dihadapi oleh institusi sekolah. Yaumi (2012:4-6) menjelaskan bahwa permasalahan di dalam pro-ses pmbelajaran tersebut berakar pada kurangnya penggalian kecerdasan siswa pada perancangan pembelajaran, strategi pembelajaran, serta evaluasi pembelajaran. Menurutnya, minat, bakat, dan kete-rampilan siswa sebagai konsep kecerdasan majemuk belum sepenuhnya diintegrasikan dalam 
proses pengembangan kurikulum di sekolah. Sedangkan pada konteks pembelajaran bahasa di Indonesia di SD, tujuan utama aspek pengembangan keterampilan berbahasa Kurikulum Tingkat Satuan Pendidikan (KTSP) tahun 2006 diarahkan pada penguasaan dan pengembangan bahasa sebagai alat komunikasi, baik secara lisan maupun tertulis.

Sementara itu, fakta pembelajaran bahasa yang dilaksanakan di sebagian besar sekolah belum menyentuh hingga tahap penggunaan bahasa Indonesia sebagai alat komunikasi atau bisa dikatakan masih sebatas pada tahap penguasaan bahasa secara keillmuan semata. Hal tersebut terjadi karena pada proses pembelajaran, siswa hanya dijejali dengan keterampilan menghafal semata, bukan pada ranah pengembangan potensi, kemampuan berpikir kritis, problem solving, dan pembentukan manusia yang kreatif serta inovatif seperti yang diharapkan (Sanjaya, 2013:2).

Pendapat tersebut didukung oleh Mutiah (2015:390) yang menegaskan bahwa salah satu penyebab tidak optimalnya pembelajaran bahasa Indonesia, terutama literasi baca dan tulis, adalah kurang tepatnya pemilihan strategi pembelajaran. Menurutnya, praktik pembelajaran bahasa di sekolah seharusnya dirancang lebih efektif dan menarik dengan mengakomodasikan berbagai inovasi pembelajaran yang sesuai, sehingga tujuan pembelajaran dapat tercapai dengan baik.

Berbicara mengenai penerapan strategi pembelajaran bahasa, pada akhir dasawarsa ini berbagai jenis pendekatan pembelajaran bahasa mengalami perkembangan begitu pesat. Menurut Richards dan Rodgers (2015: 1), sekolah-sekolah modern yang memiliki komitmen dalam hal peningkatan kualitas pembelajaran bahasa berlomba-lomba mengaplikasikan berbagai pendekatan pembelajaran bahasa tersebut di dalam proses pembelajaran di kelas sebagai langkah untuk mencapai tujuan sekolah. Salah satu teori pembelajaran yang marak digunakan dan dikembangkan menjadi pendekatan, model, strategi hingga metode pembelajaran bahasa adalah teori pembelajaran berbasis multiple intelligences atau disingkat MI atau kecerdasan majemuk.

MI pada dasarnya adalah sebuah teori yang dikenalkan secara luas oleh Howard Gardner. Melalui teori MI, Gardner menegaskan bahwa manusia memiliki beberapa kecerdasan yang dibawa sejak dilahirkan. Pada awal dicetuskannya, kecerdasan tersebut terdiri atas kecerdasan visual-spasial, logika matematika, kinestetik, interpersonal, intrapersonal, linguistik, dan kecerdasan musikal (Gardner, 1983:7-315). Berkaitan dengan teori MI, sebagai bagian dari kecerdasan verbal-linguistik di dalam pembelajaran berbasis MI, keterampilan menulis menjadi salah satu keterampilan berbahasa yang penting untuk dikembangkan sejak siswa duduk di bangku pendidikan dasar. Tanpa adanya penguasaan literasi tulis yang baik, perkembangan penguasaan keilmuan seseorang tentu saja akan terhambat. Hal tersebut didukung oleh beberapa manfaat keterampilan menulis, salah satunya, dengan penguasaan keterampilan menulis yang baik siswa dapat menuangkan ide, pemikiran, dan pengalaman serta gagasannya kepada khalayak luas di seluruh penjuru dunia dalam waktu singkat lewat publikasi karya tulis melalui berbagai media (Dombey, 2013:22).

Lunenburge dan Lunenburge (2014:1) menyatakan bahwa peningkatan antusiasme dan tinggi rendahnya tingkat penguasaan keterampilan menulis pada usia sekolah dasar bergantung pada kesesuaian antara pendekatan, strategi, dan metode pembelajaran yang digunakan oleh guru di dalam proses pembelajaran dengan jenis kecerdasan siswa. Kurangnya latihan menurut Chatib menjadi penyebab utama hambatan dalam pengembangan potensi linguistik, khususnya berbicara dan menulis (2012:81-83). Dengan kata lain, strategi serta metode pembelajaran yang digunakan belum sepenuhnya mengakomodasi kebutuhan siswa dalam hal penuangan gagasan serta ide mereka ke dalam bahasa tulis atau tulisan, sehingga kecerdasan linguistik siswa tidak berkembang sebagaimana mestinya

Pendapat tersebut sejalan hasil analisis Chatib (2012:85-87) tentang implementasi pembelajaran berbasis MI, termasuk keterampilan menulis, yang menunjukkan bahwa ada beberapa tantangan di dalam aplikasi MI di Indonesia antara lain: 1) elemen sistem pendidikan Indonesia yang kurang sejalan dengan sistem pendidikan yang profesional; 2) pemahaman yang keliru mengenai sekolah unggul; 3) desain kurikulum yang masih sentralistis; 4) penerapan kurikulum yang tidak sejalan dengan evalusi hasil akhir pendidikan; 5) proses pembelajaran berbasis MI membutuhkan kreativitas yang tinggi; 6) proses penilaian hanya dilakukan secara parsial oleh guru, terbatas pada kemampuan kognitif, masih belum menggunakan penilaian komprehensif. 
Berdasarkan latar belakang tersebut, peneliti mencoba menguraikan implementasi teori kecerdasan majemuk (multiple intelligences) yang dikembangkan Howard Gardner dan bagaimana implementasi strategi pembelajaran berbasis kecerdasan majemuk tersebut pada pendidikan untuk siswa-siswa sekolah dasar, khususnya pada pembelajaran menulis bahasa Indonesia di SD Islamic International School PSM Magetan, Jawa Timur.

\section{METODE}

Penelitian ini menggunakan pendekatan deskriptif kualitatif berupa penelitian studi kasus dengan mengambil tempat penelitian di SD Islamic International School PSM Magetan selama enam bulan yang dimulai pada pertengahan bulan Januari sampai pertengahan bulan Agustus 2018. Sumber data yang digunakan meliputi dokumen, informan atau narasumber, tempat dan peristiwa atau aktivitas berupa proses pembelajaran menulis bahasa Indonesia di kelas IV dan V SD IIS PSM Magetan.

Pengumpulan data penelitian ini menggunakan teknik analisis dokumen, pengamatan pada pelaksanaan pembelajaran, dan wawancara mendalam terhadap informan. Teknik cuplikan (sampling) yang digunakan adalah purposive (purposive sampling) dan snawball sampling. Uji validitas data yang dilakukan penulis pada penelitian ini adalah dengan triangulasi metode, triangulasi sumber, dan review informan. Teknik analisis data yang digunakan adalah analisis model interaktif (interactive model of analysis) yang dikembangkan Miles dan Huberman.

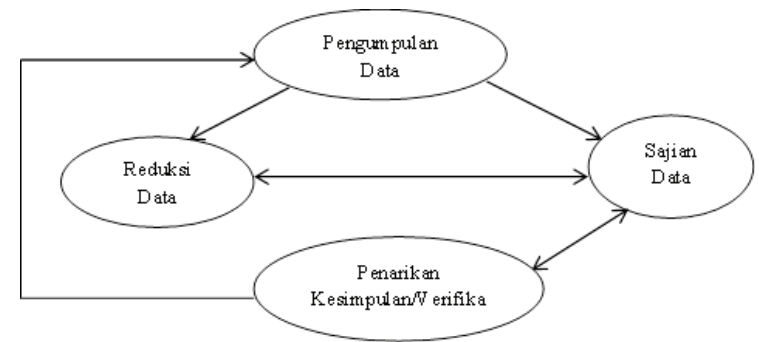

Gambar 1. Model Analisis Interaktif (Miles dan Huberman dalam Sutopo, 2006:120)

\section{HASIL}

Setiap sekolah memiliki visi dan misi untuk mendidik generasi penerus bangsa, termasuk juga SD IIS PSM. Salah satu bentuk upaya yang dilakukan oleh SD IIS PSM dalam rangka mewujudkan visi dan misi sekolah adalah dengan penerapan strategi pembelajaran berbasis multiple intelligences (MI) di dalam semua proses pembelajaran, baik kurikuler maupun kokurikuler. Penerapan startegi pembelajaran tersebut dilatarbelakangi oleh perkembangan teori kecerdasan manusia.

Di dalam pembelajaran berbasis MI, strategi pembelajaran mengacu pada silabus dan tujuan pembelajaran, sehingga proses perencanaan pun harus disusun sedemikian rupa agar pada pelaksanaan pembelajarannya berjalan dengan efektif dan efisien. Pada pembelajaran menulis dengan strategi multiple intelligences di SD IIS PSM, persiapan pembelajaran tidak hanya dilakukan oleh guru saja, akan tetapi hampir semua komponen sekolah terlibat.

Secara umum, perencanaan pembelajaran yang dilakukan oleh para guru di SD IIS PSM adalah: (1) pemetaan multiple intelligences siswa; (2) pembuatan instrumen pembelajaran yang terdiri atas AP, IP, IPO, SOW, dan LP serta instrumen penilaian pembelajaran.

Berdasarkan hasil analisis dokumen, pengamatan, dan wawancara dengan guru bahasa Indonesia, HOD of Languages, wakil kepala sekolah bidang kurikulum, dan kepala sekolah dapat dikatakan bahwa guru sudah merencanakan strategi pembelajaran menulis dengan baik. Guru telah menyusun semua instrumen pembelajaran secara lengkap, baik secara tim maupun individu dengan optimal.

Pada pelaksanaan strategi pembelajaran menulis berbasis multiple intelligences, peneliti mengacu pada tahapan pembelajaran berbasis MI. Pelaksanaan pembelajaran menulis berbasis strategi pembelajran multiple intelligences pada dasarnya meliputi (1) tahap awal atau apersepsi berupa zona alfa, warmer, dan pre-teach; (2) scene setting,; (3) strategi pembelajaran (inti); dan (4) media dan evaluasi pembelajaran.

Pada umumnya, kegiatan pembelajaran yang dilakukan guru di dalam aplikasi startegi pembelajaran menulis berbasis MI menggunakan metode yang interaktif dan variatif. Berbagai metode pembelajaran tersebut disusun serta diintegrasikan dengan berbagai jenis kecerdasan majemuk siswa Begitupun dengan penggunaan media, sumber belajar, dan materi pembelajaran. Dengan kata lain, secara keseluruhan, dapat katakan bahwa penggunaan metode pembelajaran pada pelaksanaan strategi pembelajaran menulis berbasis MI di SD IIS PSM dapat dikatakan sudah baik. 
Untuk mengetahui hasil pembelajaran yang telah dilakukan oleh siswa, maka dibutuhkan suatu penilaian. Begitu juga dengan pembelajaran menulis berbasis multiple Intelligences di SD IIS PSM. Berdasarkan hasil pengamatan, wawancara, dan analisis dokumen diketahui bahwa jenis penilaian di dalam pembelajaran menulis berbasis multiple Intelligences di SD IIS PSM adalah penilaian autentik.

Dari hasil analisis dokumen SOW dan LP, guru telah merancangkan penilaian pada kegiatan pembelajaran. Jenis dan tipe penilaian telah tertulis di dalam dokumen tersebut, akan tetapi guru tidak mencantumkan instrumen penilaian berupa perangkat tes dan rubrik penilaian menulis. Objektivitas kurang diperhatikan oleh guru dalam hal penilaian keterampilan menulis siswa.

Guru belum sepenuhnya memahami syarat penilaian yang baik. Berdasarkan hasil pengamatan, wawancara, dan anlisis dokumen, dapat dinyatakan bahwa penilaian pembelajaran menulis berbasis multiple intelligences di SD IIS PSM Magetan dapat dikatakan belum berjalan dengan baik. Konsep mengenai penilaian autentik pada dasarnya sudah cukup dipahami oleh guru bahasa Indonesia. Ketidakterlaksanaan penilaian autentik dalam pembelajaran menulis berbasis MI di SD IIS PSM disebabkan oleh kompetensi penilaian yang belum dimiliki oleh guru bahasa Indonesia. Faktor lain yang berpengaruh adalah jenis penilaian autentik yang beragam dan membutuhkan persiapan dan perencanaan yang matang. Meskipun demikian, kegiatan evaluasi pembelajaran tiap semester telah dirancang dengan cukup baik.

Evalusi pembelajaran di SD IIS PSM dilakukan 4 kali dalam satu tahun. Setiap tiga bulan sekali, siswa mengikuti kegiatan evaluasi pembelajaran. Evaluasi pembelajaran di SD IIS PSM terbagi menjadi 2 jenis tes yaitu tes formatif dan tes sumatif. Tes formatif dilakukan pada tiap akhir term 1 dan term 3. Sedangkan tes sumatif dilakukan pada term 2 dan term 4.

Strategi pembelajaran berbasis multiple intelligences merupakan salah satu langkah atau cara yang diterapkan oleh sekolah-sekolah yang mempercayai bahwa setiap individu siswa memiliki 9 jenis kecerdasan yang dapat dioptimalkan melalui perlakuan tertentu.

Hasil pengamatan dan analisis hasil wawancara, dan dokumen yang dilakukan dalam implementasi strategi pembelajaran menulis bebasis multiple intelligences di SD IIS PSM Magetan masih mengalami kendala. Kendala tersebut berasal dari berbagai faktor. Dari proses perencanaan strategi pembelajaran, proses MIR yang dilakukan oleh konselor mengalami kendala terkait validitas instrumen dan kondisifisik serta psikologi siswayang ketika mengikuti tes dalam keadaan sakit. Selain itu, Dalam perencanaan perangkat pembelajaran seperti SOW, guru belum mencantumkan hal-hal terkait dengan wujud aplikasi strategi kecerdasan jamak yang terintegrasi dengan pembelajaran menulis.

Hambatan yang lain yang dialami dalam penerapan strategi pembelajaran berbasis MI, pada umumnya, dan pembelajaran menulis pada khususnya adalah kurangnya kompetensi guru terkait dengan implementasi strategi pembelajaran tersebut. Sebagaian besar guru belum pernah mengikuti diklat pembelajaran MI, terbatasnya jumlah sumber pembelajaran berbasis multiple intelligences yang mengakibatkan guru sering mengalami kesalahan konsep di dalam pengaplikasian strategi pembelajaran berbasis multiple intelligences, sumber belajar siswa berupa buku teks yang belum berpedoman pada strategi pembelajaran berbasis multiple intelligences, dan guru mengalami kendala yang menghambat performanya sebagai guru terkait penilaian autentik pembelajaran menulis berbasis MI.

Kendala-kendala di dalam implementasi strategi pembelajaran menulis berbasiss multiple intelligences yang ditemukan di dalam penelitian ini dapat diatasi dengan baik melalui upaya-upaya yang telah dilakukan. Berdasarkan hasil pengamatan, wawancara, dan analisis dokumen pada saat proses perencanaan pembelajaran, hambatan yang dialami oleh konselor terkait dengan validitas instrumen proses MIR yang disebabkan oleh kondisi fisik dan psikologis siswa saat tes sedang tidak baik. Hal tersebut diatasi dengan melakukan tes pengamatan atau observasi secara langsung kepada siswa.

Sedangkan kendala terkait dengan perangkat atau instrumen pembelajaran seperti SOW dan LP diatasi dengan melakukan penyusunan instrumen secara bersama di tiap departemen dan melakukan konsultasi dengan HOD of Languages department. Hambatan lain terkait dengan kompetensi guru dalam penerapan strategi pembelajaran berbasis MI yang dialami oleh guru, terutama guru baru (fresh graduate), diatasi dengan pelaksanaan program atau kegiatan teachers' induction program yang 
dilakukan minimal sekali dalam satu minggu, sekolah juga merancang program training setiap liburan term (3 bulanan), dan mengirimkan guru mengikuti pelatihan dan workshop yang diadakan oleh penyelenggara pelatihan tentang multiple intelligences.

Kendala dalam pelaksanaan strategi pembelajaran berbasis MI terkait keterbatasan jumlah sumber pembelajaran bagi guru dan siswa diatasi dengan penambahan jumlah sumber belajar berupa bukubuku panduan penerapan strategi pembelajaran berbasis multiple intelligences bagi guru. Langkah lain berupa penyusunan buku teks bagi siswa, meskipun pada kenyataannya sampai saat ini masih belum selesai penyusunannya.

Di sisi lain, kendala terkait penilaian autentik yang dialami guru diatasi dengan sharing ilmu dan pembelajaran bersama antarguru mengenai jenis tes autentik beserta cara penyusunan instrumen penilaian yang baik.

\section{PEMBAHASAN}

Salah satu faktor penentu keberhasilan tujuan pembelajaran di sekolah yang harus diperhatikan setiap instisusi sekolah adalah ketepatan pemilihan dan aplikasi strategi pembelajaran. Konsep pembelajaran berbasis MI dirancang sebagai sebuah penerapan ide, konsep, dan pemikiran bahwa desain dan proses pembelajaran hendaknya memerhatikan keberagaman jenis kecerdasan majemuk yang dimiliki oleh setiap siswa.

Menurut Chatib (2014:130-131), di dalam implementasinya, strategi pembelajaran berbasis MI haruslah memuat unsur pendukung yaitu (1) strategi pembelajaran harus terkait dengan silabus, terutama indikator hasil belajar; (2) strategi pembelajaran akan lebih mudah bermanfaat jika menggunakan students-based approach atau pendekatan pembelajaran berbasis siswa; (3) pemilihan metode harus disesuaikan dengan gaya belajar siswa; dan (4) strategi pembelajaran haruslah disertai rubrik penilaian autentik.

Penelitian Widyasari $(2013,12-22)$ menunjukkan bahwa implementasi pembelajaran multiple intelligences dapat dikatakan berhasil apabila jenis instrumen pembelajaran (silabus, RPP, materi pembelajaran, dan evaluasi pembelajaran) tersedia dan ada keinginan dari guru untuk mempelajari teori serta cara penyampaian materi dengan menggu- nakan teori MI. Selain itu, guru hendaknya mampu mengatasi permasalahan yang muncul sebagai dampak implemantasi strategi pembelaaran berbasis MI dengan baik. Lebih lanjut, seorang guru juga dituntut untuk mampu mengatur manajemen kelas, memiliki interaksi, komunikai, dan hubungan yang baik dengan siswa.

Berdasarkan hasil penelitian di SD Islamic International School PSM Magetan, faktor guru memang memegang peranan yang paling utama dalam implementasi strategi pembelajaran berbasis MI, khususnya pada pembelajaran menulis. Hasil temuan peneliti pada pembelajaran menulis di kelas IV dan V menunjukkan bahwa secara keseluruhan, guru telah menyusun perangkat pembelajaran berbasis MI sejak sebelum dimulainya tahun ajaran baru. Guru menyiapkan instrumen pembelajaran berupa Action Plan (program tahunan) berdasarkan MIR. AP tersebut secara umum berisi rencana program pengembangan pembelajaran bahasa Indonesia berdasarkan 4 jenis keterampilan bahasa dan sastra.

Dokumen lain yang harus direncanakan selain silabus atau scheme of work ( $S O W$ ) adalah RPP atau lesson plan (LP). Chatib (2012:140) memaparkan bahwa sebuah RPP yang baik harus memenuhi beberapa syarat berikut (1) mengandung taksonomi bloom yang berimbang mulai dari ranah pengetahuan hingga evaluasi pada tiap kompetensi dasar; (2) terdapat kesinambungan tujuan antara standar kompetensi, kompetensi dasar, hasil belajar, dan indikator hasil belajar; (3) terdapat kesesuaian antara aktivitas pembelajaran dan hasil belajar siswa; (4) gambaran desain RPP mengikuti pola kerja otak, sedangkan aktivitas pembelajaran mewakili gaya belajar dan kecerdasan siswa, dan memiliki indikator penilaian autentik berbasis proses.

Berdasarkan hasil temuan pada penelitian ini, RPP atau LP juga disusun oleh guru bahasa Indonesia SD IIS PSM Magetan. Dokumen tersebutlah yang digunakan sebagai SOP pembelajaran di kelas. Hal tersebut sesuai dengan teori yang disampaikan oleh bahwa LP merupakan SOP guru dalam melaksanakan pembelajaran.

Mekipun demikian, sistematika penulisan RPP pembelajaran bahasa Indoenesia yang diterapkan di SD IIS PSM sedikit berbeda dengan sistematika LP seperti yang terdapat pada teori Chatib. Pada LP yang dikembangkan oleh pihak SD IIS PSM, 
beberapa istilah yang diajukan oleh Chatib tidak digunakan, istilah zona alfa kadang diganti dengan istilah brain storming. Sedangkan istilah warmer lebih sering disebut dengan istilah review, istilah pre-teach lebih dikenal dengan sebutan rules and procedures. Sedangkan istilah scene-setting di SD IIS PSM jarang sekali digunakan maupun diterapkan. Selama proses penelitian, peneliti hanya menemukan 1 kali guru memulai pembelajaran dengan scene-setting. Sementara itu, untuk bagian akhir, sistematika LP antara SD IIS PSM dan teori Chatib memiliki kesesuaian.

Berkenaan dengan proses penyusunan LP. Guru di SD IIS PSM mengacu pada persyaratan LP berbasis MI yang diajukan oleh Chatib. Taksonomi bloom (Anderson) diterapkan pada penentuan tujuan dan indikator pembelajaran. Selain itu, penentuan learning objectives juga memperhatikan keseimbangan ranah yang akan dikembangkan pada perangkat pembelajaran tersebut.

Di dalam penyusunan materi pembelajaran menulis berbasis multiple intelligences, kegiatan atau aktivitas pembelajaran yang diaplikasikan di SD IIS PSM Magetan adalah integrasi antara keterampilan menulis dengan berbagai kecerdasan majemuk. Armstrong (2013:80-115) menyatakan, strategi tersebut diantaranya: (1) strategi bertukar pikiran; (2) jurnal penulisan; dan (3) penerbitan.

Berkesesuaian dengan hasil penelitian tersebut, penyusunan materi pembelajaran menulis oleh guru bahasa Indonesia di SD IIS PSM, ketiga jenis strategi tersebut dimasukkan ke dalam rencana pembelajaran. Berdasarkan hasil temuan peneliti, strategi tukar pikiran diterapkan oleh guru pada bagian scene-setting penulisan kerangka karangan dan di bagian poses penulisan pada saat peerchecking hasil karya tulisan siswa.

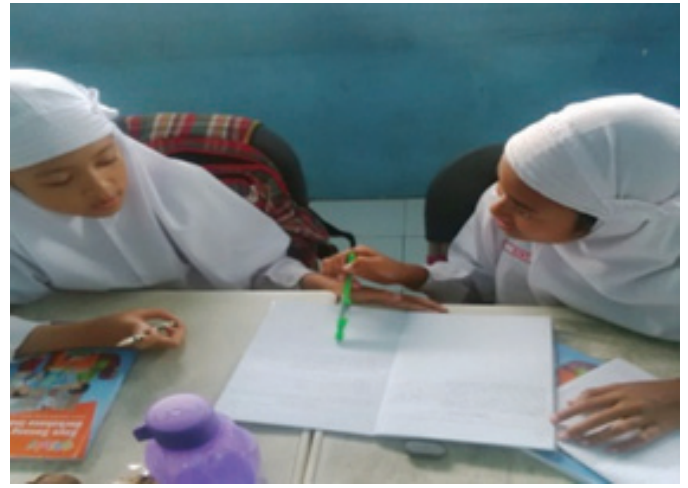

Gambar 2. Strategi Tukar Pikiran \& Peer Checking
Sementara itu, strategi penyusunan jurnal penulisan digunakan pada pembelajaran menulis karangan di kelas IV serta pada materi penulisan laporan hasil kunjungan di kelas V.

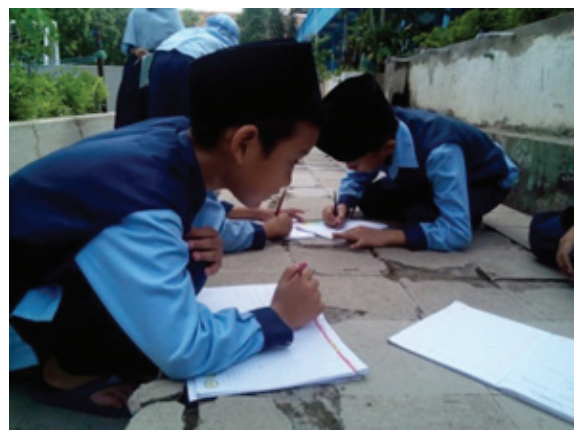

\section{Gambar 3. Strategi Jurnal Penulisan}

Sedangkan strategi penerbitan diaplikasikan oleh guru pada proyek tahunan siswa dalam rangka penulisan artikel buletin sekolah dan majalah dinding.

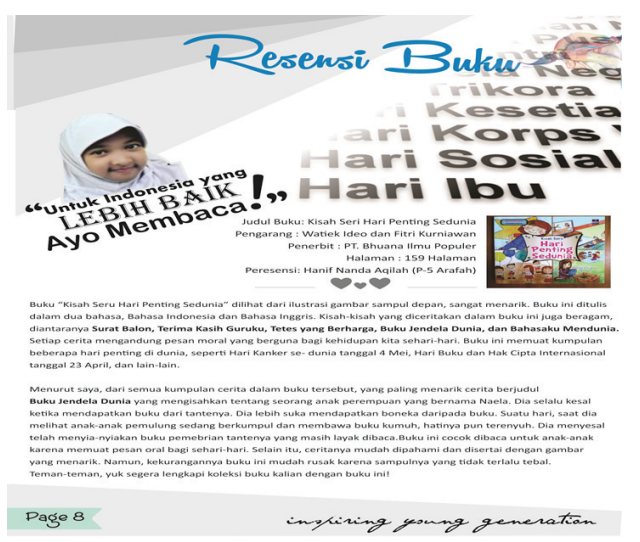

\section{Gambar 4. Hasil Karya Tulisan Siswa pada Buletin Sekolah}

Lunnenburg dan Lunnenburg (2014) melalui penelitiannya mendeskripsikan dengan detail berbagai jenis strategi pembelajaran yang dapat diterapkan pada pembelajaran menulis yaitu (1) kolaborasi dengan guru sejawat; (2) penggunaan metode pembelajaran berbasis prsentasi bagi siswa; (3) penerapan metode pembelajaran kooperatif; (4) menghadirkan tokoh (inviting speaker). Sedangkan pada assessement atau penilaian, penggunaan rubrik penilaian dan penilaian sejawat (peer-checking) dapat menjadi pilihan yang tepat dalam rangka peningkatan pembelajaran menulis berbasis MI.

Pada startegi pembelajaran kolaborasi dengan teman sejawat, peneliti tidak menemukannya pada proses pembelajaran menulis. Hanya saja, kolabora- 
si tersebut ditemukan penulis pada proses perencanaan pembelajaran berupa penyusunan instrumen pembelajaran antarguru bahasa Indonesia dan konsultasi instrumen pembelajaran antara guru bahasa Indonesia kelas IV dan V dengan HOD of Languages. Sedangkan strategi pembelajaran berbasis presentasi, pada penelitian ini ditemukan pada pembelajaran di kelas $\mathrm{V}$ pada saat scene setting terkait jenis-jenis karangan.

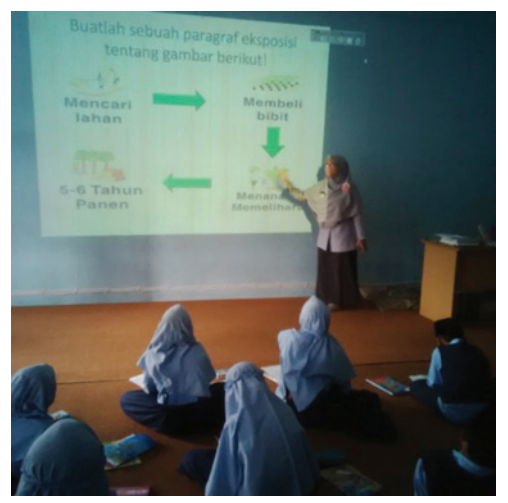

Gambar 5. Scene-setting dengan Strategi Presentasi

Strategi pembelajaran kooperatif tampak pada beberapa pengamatan yang dilakukan oleh peneliti pada proses pembelajaran. Startegi terakhir adalah inviting speakers atau menghadirkan tokoh. Pada penelitian ini, peneliti tidak menemukan penerapan strategi tersebut. Namun, temuan peneliti adalah adanya penerapan strategi pembelajaran visitasi atau kunjungan. Pada startegi kunjungan yang teramati oleh peneliti, siswa melakukan kunjungan ke kebun sekolah guna pengamatan terhadap tumbuh-tumbuhan dan situasi serta kondisi kebun sekolah.

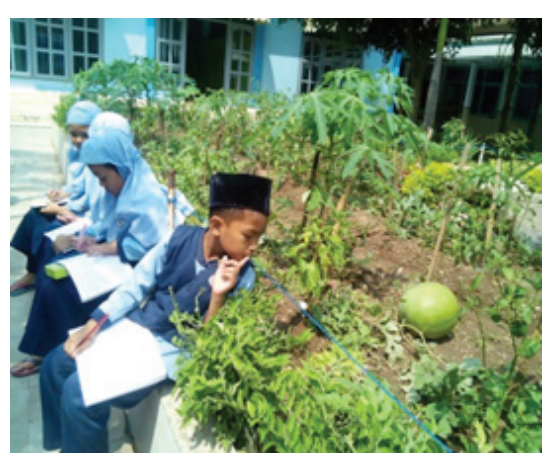

\section{Gambar 6. Strategi Kunjungan atau Visitasi}

Berdasarkan paparan tersebut, maka diketahui bahwa proses pembelajaran menulis berbasis MI di
SD IIS PSM dapat dikatakan telah berjalan dengan baik. Strategi pembelajaran yang telah diterapkan cukup bervariasi menggunakan beberapa metode yang interaktif. Selain itu, strategi pembelajaran menulis yang digunakan diintegrasikan dengan berbagai jenis kecerdasan majemuk yaitu: kecerdasan verbal-linguistik, kecerdasan visualspasial, kecerdasan intrapersonal, kecerdasan naturalis, kecerdasan interpersonal, dan kecerdasan matematis-logis.

Penilaian pembelajaran merupakan bagian penting dari kegiatan pembelajaran. Hosnan (2014:387) mengatakan bahwa penilaian yang dilakukan oleh pendidik dimaksudkan untuk mengukur kompetensi atau kemampuan tertentu terhadap kegiatan yang telah dilaksanakan dalam kegiatan pembelajaran. Melalui kegiatan penilaian, dapat diketahui apakah kompetensi yang diharapkan telah telah tercapai atau belum. Chatib (2012:163) yang membagi ranah penilaian pembelajaran berbasis MI menjadi 3 yaitu ranah kognitif, afektif, dan psikomotorik. Penilaian yang dianjurkan di dalam pembelajaran berbasis MI adalah penilaian autentik berbasis proses.

Penilaian autentik dilakukan untuk mengukur sikap, pengetahuan, dan keterampilan siswa. Penilaian-penilaian tersebut antara lain: (1) penilaian tertulis; (2) penilaian kinerja; (3) penilaian sikap; (4) penilaian produk; (5) penilaian portofolio; dan (6) penilaian diri. Berdasarkan hasil penelitian yang telah dilakukan, salah atu bentuk penilaian yang dilakukan oleh guru bahasa Indonesia pada pembelajaran menulis adalah penilaian berbasis proyek. Penelitian Bas dan Beyhan (2010) menghasilkan temuan bahwa keterampilan berbahasa Inggris dan sikap siswa dalam meningkat dengan cukup signifikan melalui metode dan jenis penilaian PBL. Pada penelitian ini, peneliti tidak memfokuskan pada peningkatan nilai siswa, namun lebih menyoroti pelaksanaan penilain tersebut. Hasil pengamatan, wawancara, dan analisis dokumen menunjukkan bahwa guru telah merencanakan penilaian tersebut di dalam LP yang disusunnya. Akan tetapi di dalam pelaksanaannya, guru tidak menyiapkan instrumen penilaian yang disebutkan.

Jenis penilaian lainnya adalah penilaian sikap. Menurut Kosasih (2013:134) Penilaian sikap dapat dilakukan melalui observasi, penilaian diri (self assessment), penilaian teman sejawat (peer assessment) oleh siswa dan jurnal. Pada temuan penelitian yang dilakukan peneliti, jenis penilaian 
yang tampak adalah penilaian diri yang terjadi pada pengamatan ke-2 dan penilaian sejawat yang tampak dilakukan pada pertemuan pertama melalui kegiatan peer-checking.

Selain penilaian melalui observasi, penilaian sikap dapat juga diperoleh melalui penilaian diri (self assessment). Penilaian diri merupakan penilaian dengan cara meminta peserta didik untuk mengemukakah kelebihan dan kekurangan dirinya dalam konteks pencapaian kompetensi (Priyatni, 2014: 180). Penilaian diri diterapkan oleh guru pada pengamatan ke-2 penelitian. Akan tetapi, guru hanya menyediakan lembar penilaian diri siswa, tanpa adanya rubrik penilaian.

Berdasarkan pembahasan hasil penelitian, dapat disimpulkan bahwa implementasi strategi pembelajaran menulis berbasis MI d SD IIS PSM Magetan secara umum sudah cukup optimal. Hal tersebut dapat diketahui dari proses perencanaan pembelajaran yang dapat dikatakan telah cukup baik, meskipun masih ada hal-hal yang perlu untuk ditingkatkan.

Secara garis besar, kendala terbesar yang dihadapi oleh guru dalam pelaksanaan pembelajaran menulis berbasis MI adalah pada penilaian autentik yang harus dilaksanakan di dalam pembelajaran.

Kesulitan pelaksanaan penilaian berawal dari perencanaan pembelajaran. Pada kegiatan perencanaan. Guru telah menetapkan jenis penilaian yang akan digunakan. Namun di dalam pelaksanaannya, guru belum membuat instrumen penilaian, baik intrumen penilaian kognitif, afektif, maupun psikomotirik. Sehingga pedoman penilaian tidak dapat dipakai pada saat kegiatan penilaian pembelajaran menulis di kelas. Kendala tersebut dilatarbelakangi oleh pehamahan guru mengenai penilaian autentik yang masih kurang.

\section{SIMPULAN DAN SARAN}

\section{Simpulan}

Berdasarkan hasil penelitian dan pembahasan dapat disimpulkan bahwa proses perencanaan pembelajaran, proses pembelajaran menulis berbasis Multiple Intelligences di SD Islamic International School PSM Magetan dapat dikatakan telah berjalan dengan baik. Sedangkan penilaian pembelajaran menulis berbasis Multiple Intelligences dapat dikatakan belum optimal. Hal tersebut dilatarbelakangi oleh minimnya pengalaman dan pengetahuan guru bahasa Indonesia mengenai aplikasi penilaian autentik.

Salah satu faktor penyebabnya adalah kurangnya sumber belajar mengenai pembelajaran menulis berbasis Multiple Intelligences. Selain itu, minimnya pelatihan juga menyebabkan guru mengalami kesulitan dalam penyusunan instrumen penilaian autentik.

\section{Saran}

Dukungan pemecahan masalah dari berbagai pihak diperlukan untuk mengatasi permasalahanpermasalahan yang menjadi kendala terlaksananya pembelajaran menulis berbasis Multiple Intelligences di SD Islamic International School PSM Magetan.

\section{DAFTAR RUJUKAN}

Armstrong, Thomas. Kecerdasan Multipel di dalam Kelas. Terjemahan oleh Dyah Widya Prabaningrum. 2013. Jakarta: PT. Indeks.

Armstrong, Thomas. Kecerdasan Jamak dalam Membaca dan Menulis. Terjemahan oleh Dyah Widya Prabaningrum. 2014. Jakarta: PT. Indeks.

Bas, Gokan Beyhan, Omer. 2010. "Effect of Multiple Intelligences Supported ProjectBased Learning on Students' Achievement Levels and Attitudes Towards English Lesson." International Electronic Journal of Elementary Education, vol. 2, issue 3, hlm. 365-386.

Chatib, Munif. 2012. Sekolahnya Manusia: Sekolah Berbasis Multiple Intelligences di Indonesia. Bandung: Penerbit Kaifa.

Chatib, Munif. 2014. Gurunya Manusia. Bandung: Penerbit Kaifa.

Chatib, Munif dan Said, Alamsyah. 2012. Sekolah Anak-anak Juara: Berbasis Kecerdasan Jamak dan Pendidikan Berkeadilan. Bandung: Penerbit Kaifa.

Dombey. 2013. "What We Know about Teaching Writing." Journal of Preschool dan Primary, vol.1, no 1, hlm. 22-40.

Gardner, Howard. 1983. Frame of Mind: The Theory of Multiple Intelligences. New York: Basics Book.

Hosnan, M. 2014. Pendekatan Saintifik dan Kontekstual dalam Pembelajaran Abad 21. Bogor: Ghalia Indonesia. 
Kosasih, Engkos. 2014. Strategi Belajar dan Pembelajaran Implementasi Kurikulum 2013. Bandung: Yrama Widya.

Lunenburg, Fred C. dan Lunenburg, Melody R. 2014. Applying Multiple Intelligences in the Classroom: A Fresh Look at Teaching Writing. International Journal of Scholary academic Intelectual Diversity, vol. 16, hlm. 1-14.

Muti'ah, Arju. 2015. Pembelajaran Bahasa Indonesia di antara Dua Kurikulum dan Peranannya dalam Pengembangan Literasi. Prosiding Seminar Konferensi Bahasa dan Sastra III. Universita Sebelas Maret, Surakarta, (pp. 386-392).

Priyatni, Endah Tri. 2014. Desain Pembelajaran Bahasa Indonesia dalam Kurikulum 2013. Jakarta: Bumi Aksara.

Richard, Jack dan Rodgers, S. 2015. Approaches and Methods in Language Teaching (Third Edition). Cambridge: Cambridge University Press.
Sanjaya, Wina. 2009. Kurikulum dan Pembelajaran: Teori dan Praktik Pengembangan Kurikulum Tingkat Satuan Pendidikan (KTSP). Jakarta: Kencana Prenada Media Group.

Sanjaya, Wina. 2013. Strategi Pembelajaran Berorientasi Standar Proses Pendidikan. Jakarta: Gramedia Grup.

Widyasari, Fibriani Endah. 2013. "The Implementation of Multiple Intelligences On The Process of Teaching and Learning English (A Case Study on Fourth Grade Students of SD Kristen 3 Klaten in The Academic Year 2012/2013)". Journal of English Teaching, vol. 1 , issue 1, hlm. 12-22.

Yaumi, Muhammad. 2012. Pembelajaran Berbasis Multiple Intelligences. Jakarta: Dian Rakyat. 